\title{
Front Matter: Volume 9550
}

, "Front Matter: Volume 9550," Proc. SPIE 9550, Biosensing and Nanomedicine VIII, 955001 (9 September 2015); doi: 10.1117/12.2205070

SPIE Event: SPIE Nanoscience + Engineering, 2015, San Diego, California, United SPIE. States 


\title{
PROCEEDINGS OF SPIE
}

\section{Biosensing and Nanomedicine VIII}

\author{
Hooman Mohseni \\ Massoud H. Agahi \\ Manijeh Razeghi \\ Editors
}

9-12 August 2015

San Diego, California, United States

Sponsored and Published by

SPIE 
The papers included in this volume were part of the technical conference cited on the cover and title page. Papers were selected and subject to review by the editors and conference program committee. Some conference presentations may not be available for publication. The papers published in these proceedings reflect the work and thoughts of the authors and are published herein as submitted. The publisher is not responsible for the validity of the information or for any outcomes resulting from reliance thereon.

Please use the following format to cite material from this book:

Author(s), "Title of Paper," in Biosensing and Nanomedicine VIII, edited by Hooman Mohseni, Massoud H. Agahi, Manijeh Razeghi, Proceedings of SPIE Vol. 9550 (SPIE, Bellingham, WA, 2015) Article CID Number.

ISSN: 0277-786X

ISBN: 9781628417166

Published by

SPIE

P.O. Box 10, Bellingham, Washington 98227-0010 USA

Telephone +1 3606763290 (Pacific Time) · Fax +1 3606471445

SPIE.org

Copyright (c) 2015, Society of Photo-Optical Instrumentation Engineers.

Copying of material in this book for internal or personal use, or for the internal or personal use of specific clients, beyond the fair use provisions granted by the U.S. Copyright Law is authorized by SPIE subject to payment of copying fees. The Transactional Reporting Service base fee for this volume is $\$ 18.00$ per article (or portion thereof), which should be paid directly to the Copyright Clearance Center (CCC), 222 Rosewood Drive, Danvers, MA 01923. Payment may also be made electronically through CCC Online at copyright.com. Other copying for republication, resale, advertising or promotion, or any form of systematic or multiple reproduction of any material in this book is prohibited except with permission in writing from the publisher. The CCC fee code is 0277-786X/15/\$18.00.

Printed in the United States of America.

Publication of record for individual papers is online in the SPIE Digital Library.

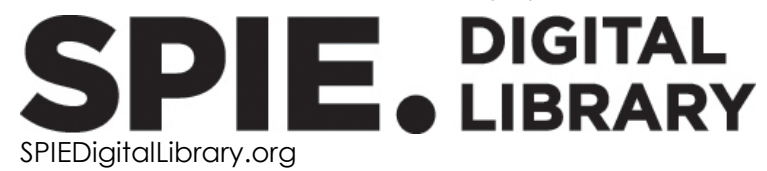

Paper Numbering: Proceedings of SPIE follow an e-First publication model, with papers published first online and then in print. Papers are published as they are submitted and meet publication criteria. A unique citation identifier (CID) number is assigned to each article at the time of the first publication. Utilization of CIDs allows articles to be fully citable as soon as they are published online, and connects the same identifier to all online, print, and electronic versions of the publication. SPIE uses a six-digit CID article numbering system in which:

- The first four digits correspond to the SPIE volume number.

- The last two digits indicate publication order within the volume using a Base 36 numbering

system employing both numerals and letters. These two-number sets start with 00, 01, 02, 03, 04, $05,06,07,08,09,0 A, 0 B \ldots 0 Z$, followed by 10-1Z, 20-2Z, etc.

The CID Number appears on each page of the manuscript. The complete citation is used on the first page, and an abbreviated version on subsequent pages. the six-digit CID number. 


\title{
Contents
}

\author{
$\checkmark \quad$ Authors \\ vii Conference Committee \\ ix Nano-bio-optomechanics: nanoaperture tweezers probe single nanoparticles, proteins, \\ and their interactions (Plenary Paper) [9544-501]
}

\section{SESSION 1 BIOSENSING I: IMAGING AND SPECTROSCOPY}

955002 Semiconductor quantum dots as delivery and imaging platforms for intracellular assembly [9550-1]

955004 Biodegradable bisphosphonate nanoparticles for imaging and therapeutic applications in osteosarcoma [9550-3]

955008 A three-camera imaging microscope for high-speed single-molecule tracking and superresolution imaging in living cells (Invited Paper) [9550-7]

SESSION 2 BIOSENSING II: SERS

9550 OA Detection of cancerous biological tissue areas by means of infrared absorption and SERS spectroscopy of intercellular fluid [9550-9]

9550 OB Surface enhanced Raman scattering for detection of Pseudomonas aeruginosa quorum sensing compounds (Invited Paper) [9550-10]

9550 OD Using Raman spectroscopy and SERS for in-situ studies of rhizosphere bacteria [9550-12]

SESSION 3 KEYNOTE JOINT SESSION WITH CONFERENCES 9550 AND 9568

9550 OF Mid-infrared ( 2.8 $\mu \mathrm{m}$ to $\sim 7.1 \mu \mathrm{m})$ interband cascade lasers (Keynote Paper) [9550-14]

9550 0G Towards novel compact laser sources for non-invasive diagnostics and treatment (Keynote Paper) [9550-15]

\section{SESSION 4 BIOSENSING AND DRUG DELIVERY}

9550 ol Evaluating mononuclear cells as nanoparticle delivery vehicles for the treatment of breast tumors (Invited Paper) [9550-17]

9550 OJ Effect of Hyp delivery system on PKCa activity: What will happen after pkca gene silencing and Hyp photo-activation? [9550-18] 
9550 OK Modified kinetics of enzymes interacting with nanoparticles [9550-19]

9550 OM Nano scaffolds and stem cell therapy in liver tissue engineering [9550-21]

9550 ON A creatinine biosensor based on admittance measurement [9550-22]

955000 Quantitative fluorescence nanoscopy for cancer biomedicine [9550-23]

SESSION 5 BIOSENSING III: PLASMONICS

9550 OP Resonant waveguide grating imagers for single cell analysis and high throughput screening (Invited Paper) [9550-24]

9550 OQ Motion behavior of mammalian AT-SC under evanescent field illumination [9550-25]

9550 OT Plasmonic nanoparticles sensors utilizing hybrid modes, electrical excitation, and anisotropic particles [9550-29]

9550 oU Wafer-scale aluminum plasmonics for fluorescence based biodetection [9550-30]

9550 OV Real-time protein aggregation monitoring based on a simultaneous light scattering investigation and a Bloch surface wave-based approach [9550-31]

\section{POSTER SESSION}

9550 OW Fluorescent Cy5 silica nanoparticles for cancer cell imaging [9550-32]

9550 0X A new molecular model for Congo Red- $\beta$ amyloid interaction: implications for diagnosis and inhibition of brain plaque formation in Alzheimer's disease [9550-33]

9550 OY Evaluation of performance of portable respiratory monitoring system based on microelectro-mechanical-system for respiratory gated radiotherapy [9550-35] 


\section{Authors}

Numbers in the index correspond to the last two digits of the six-digit citation identifier (CID) article numbering system used in Proceedings of SPIE. The first four digits reflect the volume number. Base 36 numbering is employed for the last two digits and indicates the order of articles within the volume. Numbers start with 00, 01, 02, 03, 04, 05, 06, 07, 08, 09, OA, OB...0Z, followed by 10-1Z, 20-2Z, etc.

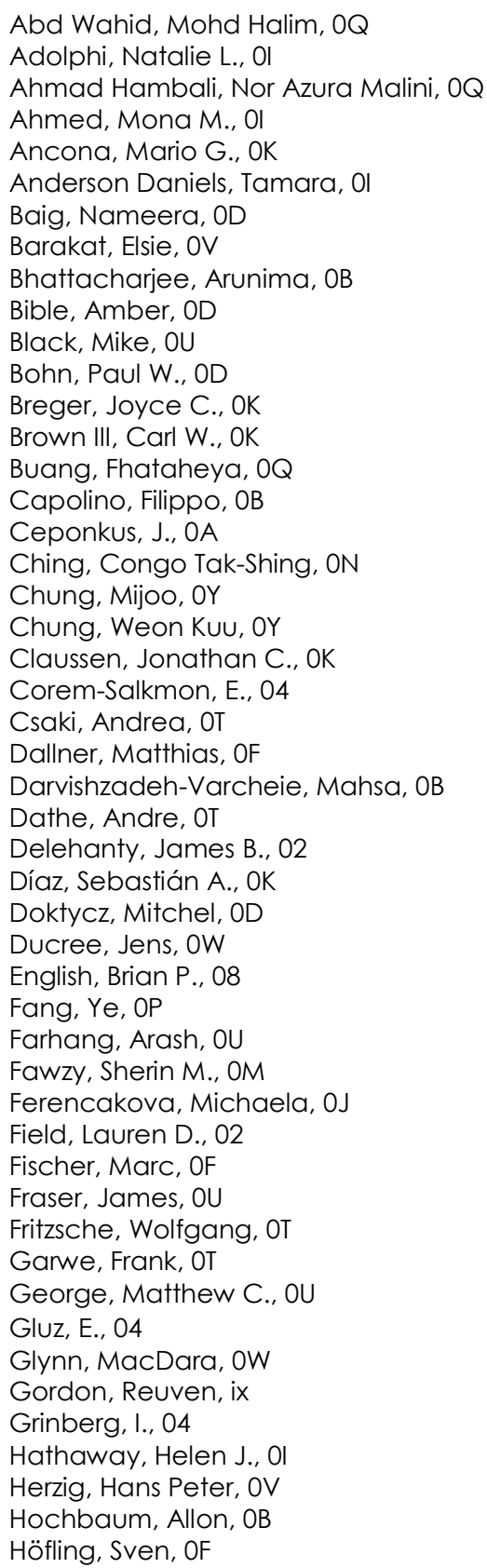

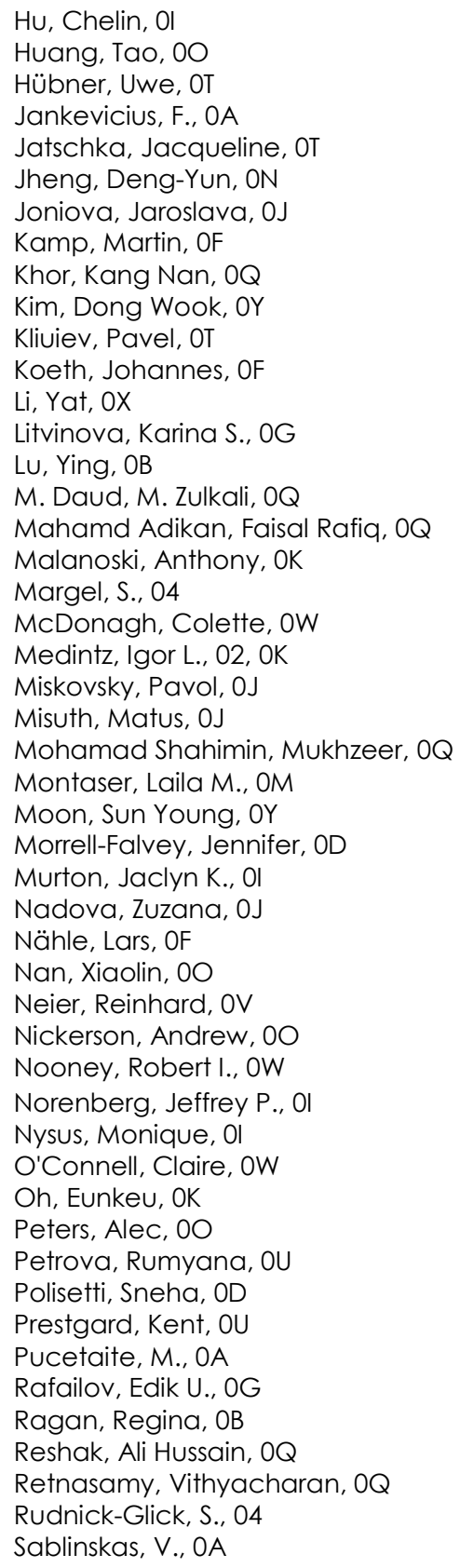


Santi, Sara, OV

Schevermann, Julian, OF

Shieh, Hsiu-Li, ON

Singer, Robert H., 08

Sokolovski, Sergei G., OG

Stewart, Michael H., OK

Stranik, Ondrej, OT

Sun, Tai-Ping, ON

Sung, Jiwon, OY

Susumu, Kimihiro, 02, OK

Thiele, Matthias, OT

Thrift, Will, OB

Trautmann, Steffen, OT

Tsai, Hou-Wei, ON

Urboniene, V., OA

Velicka, M., OA

von Edlinger, Michael, OF

Walper, Scott A., 02, OK

Wangensteen, Ted, OU

Weih, Robert, OF

Whiteson, Katrine, OB

Williamson, Brent, OU

Wirth, Janina, OT

Yoon, Myonggeun, OY

Zhang, Kristine A., OX

Ziegler, Mario, OT

Proc. of SPIE Vol. $9550955001-6$

Downloaded From: https://www.spiedigitallibrary.org/conference-proceedings-of-spie on 25 Apr 2023 Terms of Use: https://www.spiedigitallibrary.org/terms-of-use 


\title{
Conference Committee
}

\author{
Symposium Chairs
}

Satoshi Kawata, Osaka University (Japan)

Manijeh Razeghi, Northwestern University (United States)

Symposium Co-chairs

David L. Andrews, University of East Anglia (United Kingdom)

James G. Grote, Air Force Research Laboratory (United States)

Conference Chairs

Hooman Mohseni, Northwestern University (United States)

Massoud H. Agahi, Harbor-UCLA Medical Center (United States) and Cedars-Sinai Medical Center (United States)

Manijeh Razeghi, Northwestern University (United States)

Conference Program Committee

Gert Cauwenberghs, University of California, San Diego (United States)

Philippe M. Fauchet, Vanderbilt University (United States)

Guilhem Gallot, Ecole Polytechnique (France)

Ryan M. Gelfand, University of Victoria (Canada)

David H. Gracias, Johns Hopkins University (United States)

Kimberly S. Hamad-Schifferli, Massachusetts Institute of Technology (United States)

Keon Jae Lee, KAIST (Korea, Republic of)

Yu-Hwa Lo, University of California, San Diego (United States)

Ryan McClintock, Northwestern University (United States)

Omer G. Memis, Northwestern University (United States)

Masoud Panjehpour, Thompson Cancer Survival Center (United States)

Adam T. Woolley, Brigham Young University (United States)

John M. Zavada, Polytechnic Institute of New York University (United States)

Session Chairs

1 Biosensing I: Imaging and Spectroscopy

Hooman Mohseni, Northwestern University (United States) 
2 Biosensing II: SERS

Massoud H. Agahi, Harbor-UCLA Medical Center (United States) and Cedars-Sinai Medical Center (United States)

3 Keynote Joint Session with Conferences 9550 and 9568

Ruth Shinar, lowa State University of Science and Technology (United States)

Manijeh Razeghi, Northwestern University (United States)

$4 \quad$ Biosensing and Drug Delivery

Hooman Mohseni, Northwestern University (United States)

Ye Fang, Corning Incorporated (United States)

5 Biosensing III: Plasmonics

Hooman Mohseni, Northwestern University (United States) 